\title{
PERAN KEPALA SEKOLAH DALAM MENINGKATKAN MOTIVASI KERJA GURU PADA MTSN 2 KONAWE SELATAN
}

\author{
Arsam $^{1} ;$ Usman $^{2}$ \\ ${ }^{1}$ Program Studi Pendidikan Agama Islam Fakultas Agama Islam Universitas Muhammadiyah \\ Kendari \\ ${ }^{2}$ Program Studi Pendidikan Guru Pendidikan Anak Usia Dini Universitas Muhammadiyah \\ Kendari \\ e-mail: assamkendari@gmail.com, usman@umkendari.ac.id
}

\begin{abstract}
ABSTRAK: Tujuan penelitian ini adalah untuk mengetahui peran kepala Sekolah dalam meningkatkan motivasi guru pada MTs Negeri 2 Konawe Selatan. Penelitian ini adalah Kualitatif atau Naturalistik. Sumber data utama dalam penelitian ini adalah Kepala Sekolah dan Guru-guru MTs Negeri 2 Konawe Selatan. Pengambilan data penelitian dilakukan dengan cara melakukan studi dokumen, observasi dan wawancara. Data yang diperoleh akan dianalisis induktif melalui tahap redukasi data, penyajian data dan kemudian diakhiri dengan kesimpulan. Hasil penelitian ini dapat diketahui bahwa Kepala Sekolah MTs Negeri 2 Konawe selatan telah menunjukan perannya sebagai uswah (teladan) bagi mitra kerjanya dalam hal ini guru. Kepala sekolah juga telah berperan sebagai fasilitator, supporter, partsipator, instructor dan mitra kerja bagi para guru yang telah banyak memberikan motivasi kerja guru pada guru-guru MTs Negeri 2 Konawe selatan. Akan tetapi, dalam pelaksanaanya kepala sekolah dalam upaya meningkatkan kerja guru dipengaruhi oleh faktor pendukung dan penghambat. Bentuk-bentuk faktor pendukungnya seperti keikhlasan guru dalam bekerja, kesejahteraan yang selalu ditingkatkan, dan pemberian penghargaan kepala sekolah terhadap guru-guru di MTs Negeri 2 Konawe Selatan, sedangkan bentuk dari faktor penghambat adalah ketersediaan sarana dan prasarana yang masi minim, serta kurangnya ketegasan kepala sekolah terhadap guru yang indispliner dan permasalahan pribadi.
\end{abstract}

Kata Kunci: Peran Kepala Sekolah; Motivasi Kerja.

\begin{abstract}
:
The aim of this study in to knowing Efforts of principals in improving teacher work motivation at Madrasah Tsanawiyah 2 South Konawe. This research is qualitative and naturalistic. The main data source in this research is the principal and teachers of the state Mts 2 South Konawe. Research Data Collection is done by conducting a study of documents, observation, and interviews. Data obtained will be analyzed through the inductive phase of data reduction, data presentation, and then ends with a conclusion. The results of this study can be seen that the principal MTs 2 South Konawe has demonstrated its role as example for its partners in this case the teacher. Principals also have a role as a facilitator, supporter, participators, instruction and partners work for teachers who have a lot of work to motivate the teachers MTs Negeri 2 South Konawe. But in practice principals in effort improve teachers' work in influenced by factors supporting such sincerity of teachers in the work, welfare is always improved and awards principals to teachers MTs Negeri 2 South Konawe, while the shape of a limiting factor is
\end{abstract}


the availability of facilities and infrastructure is still minimal, and lack of rigor principals on teacher disciplinary and personal problems.

Keywords: Efforts of principals, work motivation.

\section{PENDAHULUAN}

Mantan menteri pendidikan nasional Wardiman Djoyonegoro dalam pernyataannya yang dikutip Mulyasa, mengungkapkan sedikitnya terdapat tiga syarat utama yang harus diperhatikan dalam pembangunan pendidikan agar dapat berkontribusi terhadap peningkatan kualitas sumberdaya manusia (SDM), yakni: (1) sarana gedung, (2) buku yang berkualitas, (3) guru dan tenaga pendidikan yang professional. Untuk poin yang terakhir disebutkan di atas, saat ini mendesak untuk diberdayakan dan ditingkatkan, baik dari segi profesionalitas maupun motivasi kerjanya. Walaupun memang diakui sebagai suatu sistem, pendidikan tidak akan terlepas dari faktor-faktor pendukung lainnya. Guru sebagai ruh dari sebuah lembaga pendidikan maka sangat penting untuk diberdayakan. Mengingat guru sebagai ujung tombak yang tidak terlepas dari kekurangan dan kelebihannya, peranan kepala sekolah sebagai manajer dalam sebuah lembaga pendidikan bertanggung jawab dalam membina bawahannya untuk mencapai tujuan yang diharapkan sesuai dengan visi dan misi yang telah ditetapkan. Terutama dalam meningkatkan motivasi kerja guru dalam membimbing dan mengarahkan siswa menjadi manusia yang berkualitas dan patut dibanggakan.

Seorang pemimpin merupakan sentral dari kegiatan yang diprogramkan. Pemimpin merupakan decision maker dan juga teladan bagi anak buahnya. Karena itu, seorang pemimpin setidaknya dapat memberikan contoh yang baik pada anak buahnya. Sebagai pembuat keputusan dan penentu kebijakan, seorang pemimpin harus memiliki satu aspek yang mempunyai peran penting dalam memimpin organisasi bersangkutan. Sebagai seorang pemimpin harus mampu melihat bawahannya dari berbagai aspek karena pada dasarnya menjadi kepala sekolah yang profesional itu tidak mudah. Banyak hal yang harus difahami, banyak masalah yang harus dipecahkan, dan banyak strategi serta teknik yang harus dikuasai. Seorang pemimpin harus mengetahui unsur-unsur kepemimpinan yang akan dapat menggerakkan bawahannya untuk berbuat yang terbaik bagi organisasi. Karena dengan demikian berarti pentingnya kepala madrasah dalam menerapkan pendekatan personal, dan strategi lainnya sehingga mampu memenuhi kebutuhan-kebutuhan mendasar bawahannya. Dan di sinilah kemampuan seorang pemimpin diuji dalam kepemimpinannya. Dalam hal ini kepala sekolah adalah yang paling berperan dan bertanggung jawab dalam mengantarkan organisasinya menjadi organisasi yang berkualitas.

Keberhasilan kepala madrasah dalam melaksanakan tugasnya terletak pada dua hal mendasar diantaranya: (1) seberapa besar kepala sekolah memahami keberadaan sekolah sebagai organisasi yang komplek dan unik; (2) seberapa besar tanggung jawabnya sebagai pemimpin sekolah dapat dipahami dan diimplementasikan dengan baik. Kondisi ini menuntut kepala sekolah untuk mampu menciptakan suasana kondusif 
sehingga tercipta kenyamanan kerja yaitu terlaksananya proses pembelajaran yang menyenangkan baik guru maupun siswa.

Madrasah sebagai lembaga pendidikan merupakan wadah mengelola mental dan moral anak bangsa yang berciri khas agama. Tidak hanya sekedar sebagai tempat menimba ilmu semata, tetapi juga sumber yang dapat mengalirkan sikap-sikap positif bagi siswa dalam menjalankan kehidupannya serta dalam menjalankan kewajiban menimba ilmu agama. Akan terasa aneh kalau siswa dan warga madrasah lainnya kurang menemukan contoh nyata yang bisa diteladani justru ditempat yang seharusnya menjadi pertunjukkan keteladanan yang dijadikan panutan adalah Nabi Muhammad SAW. Karena menjadi teladan itu lebih utama dan sulit dari pada hanya sekedar mendorong-dorong bawahan untuk melaksanakan tugasnya dengan baik.

Salah satu fungsi kepala sekolah adalah sebagai motivator. Menurut Mulyasa, sebagai motivator kepala sekolah harus memiliki strategi yang tepat untuk memberikan motivasi kepada para tenaga kependidikan dalam melakukan berbagai tugas dan fungsinya. Motivasi ini dapat di ditumbuhkan melalui pengaturan lingkungan fisik, pengaturan suasana kerja disiplin, dorongan penghargaan secara efektif, dan penyediaan sarana berbagai sumber belajar melalui pengembangan pusat sumber belajar (PSB).

Setiap tenaga kependidikan memiliki karakteristik khusus, yang berbeda satu sama lain, sehingga memerlukan perhatian dan pelayanan khusus pula dari pimpinannya. Terdapat beberapa prinsip yang dapat diterapkan kepala sekolah untuk mendorong tenaga kependidikan agar mau dan mampu meningkatkan profesionalismenya. Prinsip-prinsip tersebut adalah: (1) Para tenaga kependidikan akan bekerja lebih giat apabila kegiatan yang dilakukan menarik, dan menyenangkan; (2)Tujuan kegiatan perlu di susun dengan jelas dan di informasikan kepada para tenaga kependidikan juga dapat di libatkan dalam penyusunan tersebut; (3) Para tenaga kependidikan harus selalu di beri tahu tentang hasil dari setiap pekerjaannya; (4) Pemberian hadiah lebih baik dari pada hukuman, namun sewaktu-waktu hukuman juga di perlukan; (5) Usahakan untuk selalu memenuhi kebutuhan tenaga kependidikan; (6) Penghargaan secara efektif; (7) Penyediaan sarana berbagai sumber belajar melalui pusat sumber belajar (PSB).

\section{METODE PENELITIAN}

Jenis penelitian ini adalah penelitian lapangan (field research), sebuah penelitian dengan prosedur penelitian yang menggali data dari lapangan untuk kemudian di cermati dan di simpulkan. Adapun sifat penelitian ini adalah kualitatif atau naturalistik. Penelitian ini dilaksanakan di Madrasah Tsanawiyah Negeri 2 Konawe Selatan pada bulan Februari sampai dengan Maret 2016. Jenis data yang digunakan dalam penelitian ini dapat diklasifikasikan menjadi dua jenis data, yaitu sebagai berikut: (a) Data primer yakni data yang di peroleh dari sumber utamanya tanpa perantara, dalam hal ini data yang di dapat melalui wawancara dari informan (Kepala Sekolah, Guru dan Staf); dan (b) Data sekunder yakni data yang di peroleh melalui perantara, seperti melalui dokumen- 
dokumen yang penting yang di butuhkan dalam penelitian ini, misalnya data tentang jumlah kelas, jumlah personal sekolah, keadaan sekolah dan sebagainya.

Teknik pengumpulan data dalam penelitian ini berupa wawancara, observasi dan dokumentasi. Analisis data yang digunakan dalam penelitian ini bersifat induktif. Adapun prosesnya dilakukan bersamaan dengan pengumpulan data melalui beberapa tahapan. Model seperti ini disebut dengan Analysis Interactive Model sebagaimana yang dikemukakan oleh Miles dan Huberman bahwa analisis data dimulai dengan proses pengumpulan data, reduksi data, penyajian data dan kemudian di akhiri dengan verifikasi atau penarikan kesimpulan.

\section{HASIL PENELITIAN DAN PEMBAHASAN}

Kepala sekolah memiliki peranan yang sangat besar dalam meningkatkan motivasi kerja guru. Hal ini tidak terlepas dari tanggung jawab kepala sekolah sebagai seorang pemimpin dalam maju mundurnya sekolah tergantung pada pimpinannya dalam hal ini kepala sekolah. Kiranya tidak berlebihan jika Wahjosumidjo mengeluarkan pernyataan bahwa keberhasilan sekolah adalah keberhasilan kepala sekolah.

Keberadaan MTsN 2 Konawe Selatan yang berdiri dengan semangat memberikan layanan pendidikan untuk warga sekitar dalam perjalanan waktu yang cukup panjang sampai saat ini masih dipimpin oleh kepala sekolah yakni Bapak Syarif, S.Ag, M.Pd.I., telah menjadi kepala sekolah selama \pm 2 tahun. Dalam kesehariannya, kepala sekolah MTsN 2 Konawe Selatan dihadapkan pada karakter guru dan staf yang memiliki latar belakang yang berbeda kepentingan dan tingkat sosial sehingga di mungkinkan menimbulkan konflik antar individu terutama jika dihadapkan pada masalah-masalah yang muncul. Untuk itu dalam mengatasi masalah tersebut, kepala sekolah dalam menjalankan tugasnya sebagai pemimpin perlu memiliki kompetensi sebagai mana telah dikemukakan pada bab sebelumnya mengenai kompetensi-kompetensi yang patut dimiliki seorang kepala sekolah.

Guru dan karyawan merupakan faktor penting dalam menunjang proses belajar mengajar. Namun, guru dapat menjadi masalah jika tidak dikelola dengan baik. Perbedaan karakter pribadi, latar belakang dan kepentingan semua ini dapat menjadi sumber permasalahan sehingga situasi di sekolah menjadi tidak kondusif.

Sehubungan dengan perbedaan-perbedaan yang dimiliki guru dan karyawan, dibutuhkan peran kepala sekolah untuk mengidentifikasi karakter dan semua pemberian tugas disesuaikan dengan kompetensinya masing-masing. Hasil wawancara yang dilakukan dengan kepala sekolah MTsN 2 Konawe Selatan dalam mengelola guru lebih mempertimbangkan pada kesiapan dan kemampuannya masing-masing. Langkah ini merupakan bentuk kebijaksanaan kepala sekolah dalam memahami apa yang di inginkan dan dirasakan bawahannya. Perlu digaris bawahi, menurut Rupert Eals bahwa salah satu alasan yang mengidentifikasikan lemahnya kepemimpinan adalah kebijaksanaan. Hal ini sangat sesuai dengan tuntutan luhur dalam ajaran islam, bahwa setiap manusia adalah pemimpin dan setiap pemimpin akan di mintakan pertanggungjawaban atas apa yang dipimpinnya. Seorang kepala sekolah juga merupakan kedudukan pimpinan yang membawahi beberapa orang yang berada dalam 
pengawasan dan tanggung jawabnya. Oleh sebab itu, sebagai seorang pemimpin, kepala sekolah tidak hanya berperan dan bertugas sebagai pengambil keputusan, akan tetapi ia harus mampu membina, membimbing dan mengarahkan setiap orang yang ada dibawah kekuasaannya untuk dapat melaksanakan tugas dan tanggung jawabnya dengan benar dan sesuai dengan nilai-nilai luhur dalam ajaran agama Islam.

Berdasarkan hasil wawancara, observasi dan dokumentasi yang dihimpun penulis, dapat disimpulkan bahwa peran kepala sekolah yang dapat dirasakan oleh guruguru MTsN 2 Konawe Selatan dikaitkan dengan tuntutan luhur ajaran Islam adalah sebagai berikut:

1. Uswah (teladan)

2. Siddiq (Jujur/Benar)

3. Amanah (dapat dipercaya)

4. Tablig (Menyampaikan)

5. Fatanah (bijaksana dan cerdas)

Faktor pendukung motivasi kerja pada MTsN 2 Konawe Selatan adalah Keikhlasan bekerja, peningkatan kesejahteraan, dan penghargaan kepada guru. Berdasarkan hasil wawancara dengan Ibu Dede Fitriani, S.Pd dan Irawati, S.Pd., guru non PNS keduanya menyatakan bahwa faktor kesejahteraan tidak menjadi tujuan utama mereka dalam mengajar. Menurut pengakuan keduanya, menimba pengalaman dan memberikan ilmu terhadap siswa-siswi adalah yang paling utama. Hal ini dapat dilihat dari semangat guru untuk bekerja dengan penuh loyalitas. Pengakuan yang sama pula dikemukakan oleh beberapa guru mata pelajaran. Mereka tidak mempersoalkan masalah kesejahteraan, karena pada umumnya mereka meyakini bahwa kesejahteraan akan mengikuti dengan sendirinya bila pekerjaan tersebut dilakukan dengan baik dan seiring membaiknya keadaan keuangan madrasah. Upaya untuk selalu para mensejahterakan para guru dan karyawan di MTsN 2 Konawe Selatan selalu dilakukan dengan memberikan prioritas utama. Hal ini ditunjukkan degan besarnya anggaran belanja sekolah hamper $50 \%$ untuk kesejahteraan guru. Selanjutnya dari hasil wawancara dapat diketahui bahwa kepala sekolah sangat menghargai guru. Sikap menghargai kepala sekolah ini ditunjukkan dalam forum musyawarah dengan tidak memaksakan kehendak sendiri. Kepala sekolah termasuk orang yang cukup demokratis. Memaksakan kehendak sendiri kepala sekolah termasuk orang yang cukup demokratis.

Faktor penghambat motivasi kerja pada MTsN 2 Konawe Selatan adalah sarana dan prasarana yang minim, minimnya ketegasan kepala sekolah, dan permasalahan pribadi. Sarana dalam pelaksanaan proses belajar mengajar pada umunya yang ada di Indonesia adalah ketersediaan ruang kelas beserta sarana penunjang pendidikan lainnya. Sebagaimana dikemukakan oleh Mulyasa, bahwa sarana prasarana merupakan termasuk faktor yang mampu memberikan motivasi terhadap guru-guru dalam bekerja. Kondisi sarana dan prasarana yang ada di MTsN 2 Konawe Selatan seperti yang dikemukakan oleh beberapa guru adalah sangat minim. Di bandingkan dengan jumlah siswa yang rata-rata berjumlah 35 perkelasnya, yang dibagi dalam 8 atau 9 rombongan belajar. Kepala sekolah sebagai puncak pimpinan kurang memiliki ketegasan dalam 
mengambil keputusan terutama jika dihadapkan pada perilaku guru yang indisipliner. Kekurang tegasan ini menyebabkan guru-guru yang tidak memiliki kinerja baik masih dipertahankan tanpa diberikan sanksi. Akibatnya proses belajar mengajar pun terganggu sehingga berpengaruh pada jadwal kegiatan berikutnya. Permasalahannya pribadi pada dasarnya adalah masalah internal yang biasanya berkaitan dengan masalah-masalah yang dihadapi guru di rumah atau keluarga. Hal ini disebabkan latar belakang keluarga yang berbeda-beda yang dimiliki guru seperti yang di ungkapkan Ibu Dede Hanifa, S.Pd. Masalah pribadi tersebut secara tidak langsung menurut pemaparan keduanya dapat menyebabkan motivasi kerja menurun atau meninggalkan tugas karena membutuhkan penyelesaian secepatnya.

\section{KESIMPULAN}

Peran kepala sekolah dalam peningkatan motivasi kerja guru di MTsN 2 Konawe Selatan berdasarkan studi Islam meliputi perannya sebagai uswah (teladan) bagi mitra kerjanya dalam hal ini guru, siddiq (jujur/benar), amanah (dapat dipercaya), tablig (menyampaikan/mengajak kepada kebaikan), dan fathonah (cerdas/bijaksana). Hal tersebut, secara langsung dapat memberikan dampak pada perbaikan perilaku dan kinerja guru dan para bawahannya yang berada di bawah kepemimpinannya. Faktor pendukung dan penghambat motivasi kerja guru di MTsN 2 Konawe Selatan sebagai berikut: (a) Faktor yang telah mendukung terciptnya motivasi kerja guru di MTsN 2 Konawe Selatan meliputi: keikhlasan guru dalam bekerja, kesejahtaraan yang selalu ditingkatkan dan pemberian penghargaan kepala sekolah terhadap guru-guru di MTsN 2 Konawe Selatan; (b) Faktor penghambat dalam terciptanya motivasi kerja guru di MTsN 2 Konawe Selatan meliputi: sarana dan prasarana yang minim, minimnya ketegasan kepala sekolah terhadap tindakan guru yan indisipliner, dan permasalahan pribadi.

\section{UCAPAN TERIMA KASIH}

Penulis mengucapkan terima kasih kepada Universitas Muhammadiyah Kendari yang telah memberikan dukungan finansial dalam penelitian ini.

\section{DAFTAR PUSTAKA}

Mulyasa Enco, (2007). Menjadi Guru Profesional, Menciptakan Pembelajaran Kreatif dan Menyenangkan, Bandung: PT.Remaja Rosdakarya.

Mulyasa Enco, (2005). Menjadi Kepala Sekolah Profesional Dalam Konteks Menyukseskan MBS dan KBK, Bandung: PT.Remaja Rosdakarya.

Mulyasa Enco, (2003). Manajemen Berbasis Sekolah, Bandung: PT.Remaja Rosdakarya. Muhammad Saroni, (2006), Manajemen Sekolah, Yogyakarta: Ar-Ruzz Media.

Sugiyono, (2009). Metodologi Penelitian Kualitatif, Penelitian Kuantitatif dan R\&D, Bandung: Alfabeta.

Suharsini, Arikunto, (1997). Prosedur Penelitian, Suatu Pendekatan Praktek, Jakarta: Rineka Cipta.

Wahyusumidjo, (2002). Kepemimpinan Kepala Sekolah, Tinjauan Teoritik dan Permasalahannya, Jakarta: Raja Grafindo Persada.

Winarno, (2015). Kimia Pangan dan Gizi. Jakarta: Gramedia Pustaka Utama. 